\title{
Crosstalk Mechanisms Following Targeted Therapy in Head and Neck Cancer
}

\author{
Hyung Kwon Byeon \\ Department of Otorhinolaryngology, Gangnam Severance Hospital, Yonsei University College of Medicine, Seoul, Korea
}

\section{두경부암의 표적 치료제 저항성 기전}

변 형 권

연세대학교 의과대학 강남세브란스병원 이비인후과학교실

Received January 4, 2016

Revised January 26, 2016

Accepted January 29, 2016

Address for correspondence

Hyung Kwon Byeon, MD, PhD

Department of Otorhinolaryngology,

Gangnam Severance Hospital,

Yonsei University

College of Medicine,

211 Eonju-ro, Gangnam-gu,

Seoul 06273, Korea

Tel +82-2-2019-3468

Fax $+82-2-3463-4750$

E-mail ewell@yuhs.ac
Head and neck squamous cell carcinoma has emerged as the sixth most commonly occurring cancer worldwide and despite advances in diagnostics and therapeutics, the treatment results and survival outcomes still remain poor, especially in advanced cancers. Due to the complexity of the local anatomic structures and the importance as vital functioning organs, the head and neck area following conventional treatment modalities such as surgery, chemotherapy, or radiotherapy often result as a devastating consequence both esthetically and functionally. In order to minimize the treatment related sequelae and at the same time maximize treatment effect, tumor-specific molecular targeted therapy has become an area under active research. Several molecular targeted agents, including the representative epidermal growth factor receptor (EGFR)inhibitors have been developed and its therapeutic effects investigated. However, therapeutic resistance has newly risen as a main problem following targeted therapy due to a variety of resistance mechanisms. This review article looks at the major acquired resistance mechanisms following targeted agents administration including EGFR inhibitors and many others and strategies to overcome the resistance to achieve precision medicine.

Korean J Otorhinolaryngol-Head Neck Surg 2016;59(3):181-7

Key Words Epidermal growth factor receptor $\cdot$ Head and neck cancer $\cdot$ Resistance Squamous cell carcinoma · Targeted therapy.

\section{서 론}

구강, 인두 및 후두를 포함하는 두경부암은 기관별 암 발생 률이 암 중에서 6번째를 차지하며, 미국에서만 매년 40000명, 전 세계적으로 600000 명의 두경부암 환자가 발생할 만큼 흔 한 암이다. ${ }^{1}$ 최근 들어 진단과 치료 기술의 발달로 치료 성적 이 많이 향상되었지만 진행성 두경부암의 경우에 있어서 5년 생존율은 $50 \%$ 를 넘지 못하고 있으며, 전 세계적으로 매년 약 300000 명의 환자가 사망에 이르게 된다. 두경부암 치료의 어려운 점은 국소전이가 많고 원격전이도 흔하며, 소위 호흡, 발성 및 연하 기관에 혹은 근접하여 암이 발생하게 되면 치 료 후에 여러 가지 해부학적, 미용적, 기능적인 장애를 초래하
게 된다. 중요 장기와 근접하여 수술적인 치료 시 충분한 절 제연의 확보가 어려워 항암/방사선치료 단독 또는 동시항암 방사선 병합치료를 시행하는 경우가 흔하고 그럼에도 불구하 고 재발이 많아 치료에 어려움이 있다. 따라서 치료 부작용을 최소화하면서 효과적으로 암세포를 선택적으로 치료할 수 있는 치료법(targeted therapy)의 개발이 절실한 실정이다.

두경부암에서 종양세포 특이적인 표적치료는 독성을 최소 화하고, 치료 효과를 향상시킬 것으로 기대 되는데, gene therapy, monoclonal antibodies(mAb), antibody-drug conjugates, small molecule inhibitors, antisense molecules, tumor vaccines 등과 같은 다양한 치료제들이 두경부암 세포 를 표적으로 하여 개발 중에 있다. 표적 치료제들은 암세포 
가 특징적으로 가지고 있는 분자를 표적으로 하여 그 효과를 나타내도록 고안되어 암세포의 신호전달경로(signal transduction pathway), 혈관신생(angiogenesis), 세포외간질(extracellular matrix), 세포주기 조절인자(cell cycle regulator), 세포사멸(apoptosis) 등 다양한 표적에 작용하도록 개발되었다.

두경부암의 $90 \%$ 이상이 조직학적으로 편평세포암종(squamous cell carcinoma)이며 두경부 편평세포암종의 약 $90 \%$ 에서 상피세포 성장 인자 수용체(epidermal growth factor receptor; EGFR/ErbB1/HER)의 발현이 확인되고 있어 EGFR 이 두경부암에서 가장 많은 연구가 이루어진 분자 표적이라 할 수 있다. EGFR의 높은 발현은 생존율 감소, 방사선치료에 대 한 저항성, 국소 치료 실패와 원격 전이의 증가와 연관이 있는 것으로 알려져 있다. EGFR은 막횡단 단백 세포 표면 수용체 (transmembrane protein cell surface receptor)이고, $170 \mathrm{kDa}$ 의 당단백으로서 ErbB2(HER2/neu), ErbB3(HER3), ErbB4 (HER4)와 함께 ErbB/HER family의 member이다. EGFR의
리간드로는 EGF, transforming growth factor- $\alpha(\mathrm{TGF}-\alpha)$, amphiregulin, epiregulin, betacellulin, 그리고 heparin-binding $\mathrm{EGF}$-like growth factor 등이 있고, 리간드와 결합한 EGFR은 타이로신 키나아제(tyrosine kinase) 효소 활성을 나타내어 MAPK, phosphatidylinositol-3-kinase(PI3K)/ AKT/mammalian target of rapamycin(mTOR), signal transducer and activator of transcription(STAT) 등의 신호 전달 경로를 증가시켜 세포 성장, 발달 및 분화에 중요한 역할을 한다(Fig. 1).

$\mathrm{EGFR}$ 를 표적으로 하여 개발된 표적 치료제들로는 대표적 으로 cetuximab(Erbitux ${ }^{\circledR}$ Bristol-Myers Squibb, New York, $\mathrm{NY}, \mathrm{USA})$ 과 같은 단일클론항체(mAb)와 gefitinib(Iressa ${ }^{\circledR}$ AstraZeneca, London, UK), erlotinib(Tarceva ${ }^{\circledR}$ Genetech, San Francisco, CA, USA), lapatinib(Tykerb ${ }^{\circledR}$ GlaxoSmithKline, Philadelphia, PA, USA)과 같은 저분자 타이로신 키나 아제 억제제(small-molecule tyrosine kinase inhibitors, TKI)

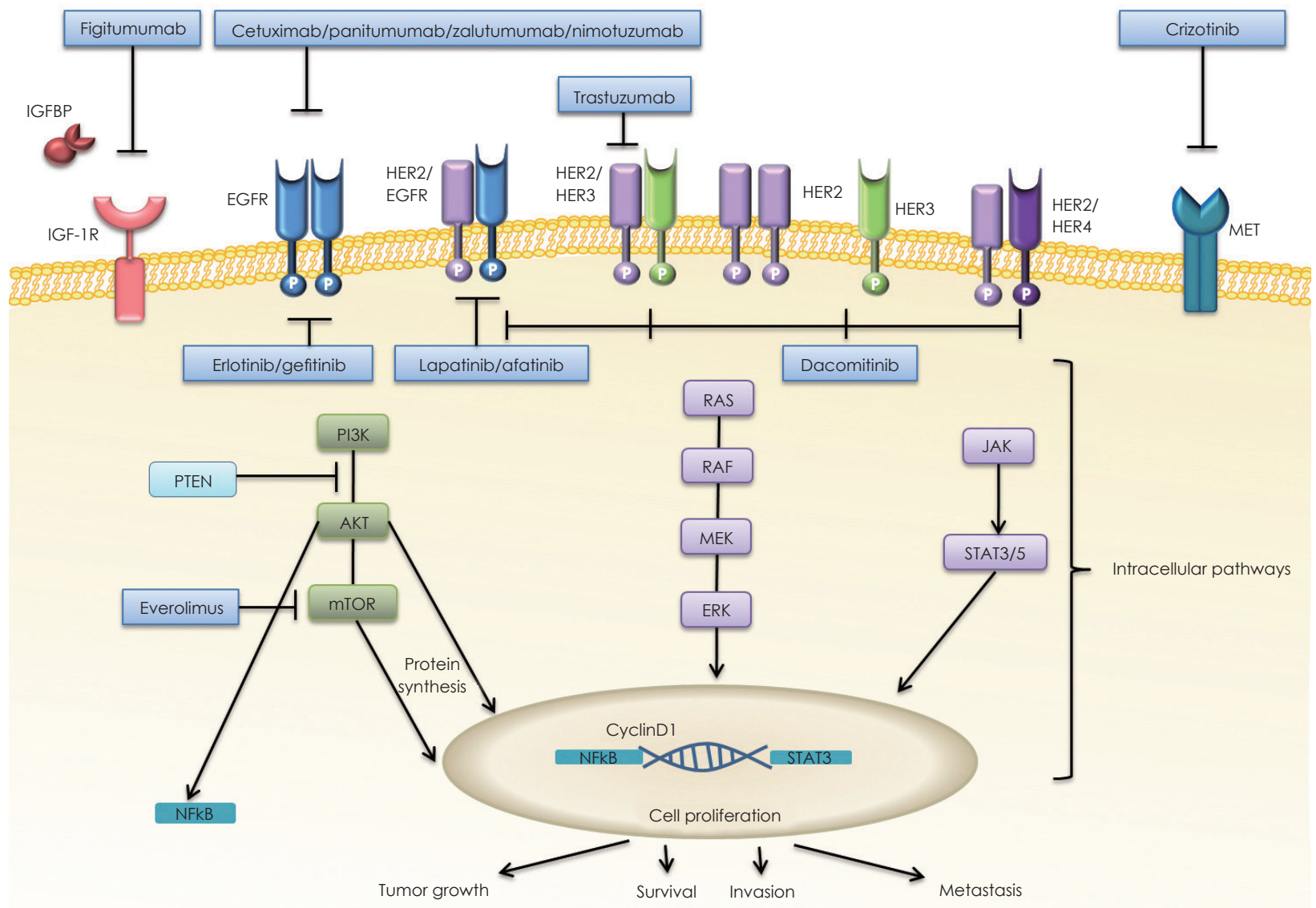

Fig. 1. Receptor tyrosine signaling pathways and intracellular responses involved in head and neck squamous cell carcinoma. Potential molecular targets and some representative existing targeted agents are also depicted. EGFR: epidermal growth factor receptor, ERK: extracellular signal-regulated protein kinase, HER: human epidermal growth factor receptor, IGFBP: insulin-like growth factor binding protein, IGF-1R: insulin-like growth factor-1 receptor, JAK: janus kinase, MEK: mitogen activated protein kinase, mTOR: mammalian target of rapamycin, NFKB: nuclear factor kappa-light-chain-enhancer of activated B cells, PI3K: phosphatidylinositol-3-kinase, PTEN: phosphatase and tensin homolog, RAF: v-raf-1 murine leukemia viral oncogene homolog, RAS: rat sarcoma viral oncogene homolog, STAT: signal transducer and activation of transcription. 
가 있으며 cetuximab은 현재 유일하게 두경부 편평세포암종에 서 Food and Drug Administration과 European Medicines Agency에서 승인을 받은 표적 치료약제이다(Fig. 1). 그러나 이러한 종양세포 특이적인 표적 치료제들은 처음 기대와는 달리 약효 면에서 제한적인 결과를 보여 내인성(innate) 혹은 후천성(acquired) 저항성 기전 발현의 가능성이 대두되었다. 특 히 다른 암에서와 마찬가지로 두경부암에서 여러 신호경로 간 의 상호간섭(crosstalk)으로 인한 저항성이 중요하게 부각되고 있다. 이에 두경부암에 대한 EGFR 억제제를 비롯하여 다른 표적 치료제에서 보이는 crosstalk mechanism을 비롯하여 저 항성의 대표적인 기전에 관해 이루어지고 있는 연구 경향을 살펴보고 이를 극복하기 위해 시도되고 있는 다양한 최신 전 략들을 알아보고자 한다.

\section{본 론}

\section{$\mathrm{EGFR}$ 표적 치료 저항성의 기전과 극복 전략}

$\mathrm{EGFR}$ 이 두경부 편평세포암종의 거의 모든 경우에 높게 발 현됨에도 불구하고 이 발현 수준이 환자 개개인의 EGFR 표 적 치료의 반응성을 예측할 수 있다는 증거는 없다. 폐암이나 유방암과는 달리 두경부암은 동일한 편평세포암종 간에도 그 이질성(heterogeneity)이 특징이며, EGFR 표적 치료제에 다 양한 정도의 치료 반응성을 보인다. EGFR 억제제에 대한 많 은 임상연구를 통해 환자의 10 20\%에서만 뚜렷한 효과를 보이며 약 $80 \%$ 정도에서는 유의한 반응을 보이지 않는다(내 인성 저항성). 더군다나 처음의 효과와는 달리 EGFR 억제제 를 투여하게 됨에 따라 나타나는 후천성 저항성 또한 보이게 된다. 두경부암에서는 $\mathrm{EGFR}$ 표적 치료제의 저항성을 유발하 는 일관된 공통된 기전이 존재하지 않으며, 이러한 약제 저항성 의 원인은 크게는 다음과 같이 정리할 수 있다. 1) EGFR의 다 양한 발현 수준, 2) 상부 신호전달 억제에도 불구하고 EGFR 과 crosstalk 혹은 피드백 조절 기전으로 활성화되는 다른 신 호전달 체계, 3) EGFR 억제에 저항성을 유발하는 유전적 돌 연변이 때문이다.

\section{Activation of crosstalk mechanism}

$\mathrm{EGFR}$ 억제제에 대한 저항성 기전에 관한 많은 연구로 밝혀 진 부분이 EGFR 억제 투여 후 발현되는 다른 신호 기전 혹 은 EGFR을 경유하지 않는 하부신호전달 체계의 활성화를 통한 extracellular signal-regulated protein kinase(ERK) $1 / 2$ 신호전달 증가이다. EGFR이 과활성화되어 다른 $\mathrm{HER}$ family member 수용체, 특히 HER2, HER3 수용체와 heterodimerization를 통해 EGFR 이상 신호 증가를 가져오게 된
다(Fig. 1). Yonesaka 등른 $\mathrm{EGFR}$ 억제제 투여 후 HER2 증 폭 혹은 heregulin upregulation에 의해 HER2 신호 증가가 나타나게 되며, 그 결과 ERK $1 / 2$ 과 HER3의 활성화를 통한 $\mathrm{PI} 3 \mathrm{~K} / \mathrm{AKT}$ 의 지속적인 과활성이 야기되어 cetuximab에 대한 후천성 저항성이 유발된다고 보고하였다. 따라서 이러한 경우 $\mathrm{EGFR}$ 과 HER2를 동시 억제하거나 HER2와의 heterodimerization을 억제하면 EGFR 억제제에 대한 저항성이 회복되는 것을 확인하였고 EGFR, HER2 dual inhibitor TKI인 lapatinib(가역적) 혹은 afatinib(비가역적) 그리고 gefitinib과 함께 $\mathrm{HER} 2$ 를 표적으로 하는 mAb인 pertuzumab을 병합 치료하 는 임상 연구가 진행 중이다. ${ }^{3,4)}$

Cetuximab 저항성을 보이는 암세포주에 Src family kinase (SFK)가 과활성화되어 EGFR, HER3, 그리고 PI3K/AKT 신 호전달을 증가시킨다는 보고가 있다. ${ }^{5)}$ 따라서 여기에 Src kinase 억제제인 dasatinib을 처리하였을 때 HER3의 활성을 감소시키고 $\mathrm{PI} 3 \mathrm{~K} / \mathrm{AKT}$ 신호전달을 억제시켜 cetuximab의 감 수성을 회복시킨다는 것을 확인하였다. 또한 $\mathrm{EGFR}$ 억제에 저항성을 보이는 두경부암세포주에 STAT3 신호가 증가되어 있음을 발견하여 cetuximab 혹은 EGFR TKI와 함께 STAT3 억제제를 동시 투여했을 때 종양 억제 효과가 있었음을 보고 한 연구도 있다.

EGFR과 crosstalk를 보이는 다른 타이로신 키나아제 수용 체(receptor tyrosine kinase, RTK)가 활성화되어 이를 통해 EGFR 억제 TKI에 대한 저항성을 보이는 경우도 있는데 그 대 표적인 것이 cMET(hepatocyte growth factor receptor)이 다. 두경부암의 $80 \%$ 에서 cMET 과발현이 확인된 바 있으며 $\mathrm{cMET}$ 활성화로 인해 증가된 HER2와 HER3가 EGFR 억 제의 저항성에 관여한다고 보고되었다. ${ }^{7)}$ 즉, EGFR이 억제가 되었음에도 $\mathrm{cMET}$ 은 온전하게 하부신호전달을 하게 되는데, 이를 oncogene bypass라고 한다. cMET 억제제와 erlotinib 의 병합요법이 HER3/AKT 신호전달 억제를 통해 암세포 성 장 억제에 상승효과를 나타낸다고 보고된 바가 있다. ${ }^{8)}$ 또한 이 밖에도 EGFR이 비수용체인 Src 타이로신 키나아제를 통해 cMET를 인산화시켜 활성화시킨다는 연구 결과도 있다. ${ }^{9)} \mathrm{In}-$ sulin-like growth factor 1 receptor(IGF-1R)은 세포의 성장, 증식, 분화, 혈관신생 및 생존에 관여하는 RTK로서 IGF, EGF 에 의해 자극을 받아 활성화되며 EGFR과 heterodimerization 을 일으켜 하부 신호로 MAPK, PI3K/AKT/mTOR 경로를 활성화시켜 $\mathrm{EGFR}$ 에 대한 저항성을 가지게 된다. ${ }^{10)} \mathrm{IGF}-1 \mathrm{R}$ 은 두경부암의 약 $70 \%$ 에서 발현되며 불량한 예후와 연관이 있다는 보고가 있다. ${ }^{11)} \mathrm{IGF}-1 \mathrm{R}$ 의 mAb인 figitumumab과 IMC$\mathrm{A} 12$ 등이 개발되어 단독 요법 혹은 cetuximab과의 병합요법 에 대해 여러 연구가 진행 중이다. ${ }^{12)}$ 


\section{III형 유전 변이(EGFR variant III)}

비소세포폐암(non-small cell lung cancer)과는 달리 두경 부암에서는 EGFR의 타이로신 키나아제 영역의 돌연변이는 드문 편이다. EGFR의 리간드가 결합하게 되는 세포외 영역 의 결손으로 항시 활성화를 보이는 EGFRvIII 돌연변이형은 두경부암에서 0 40\%의 다양한 정도의 발현 양상을 보인다. ${ }^{13)}$ 따라서 이러한 경우, cetuximab과 같은 $\mathrm{mAb}$ 약제에 대해서는 저항성을 보이게 되며, afatinib과 같은 비가역적으로 EGFR 를 억제하는 TKI가 효과가 있다는 임상연구가 진행 중이다.

\section{Rat sarcoma viral oncogene homolog(RAS) 돌연변이}

대장암에서 cetuximab의 저항성에 V-Ki-ras2 Kirsten rat sarcoma viral oncogene homolog(KRAS) 돌연변이가 관여 하여 EGFR의 하부 신호전달 체계인 MAPK나 PI3K/AKT 신호전달을 지속적으로 활성화시킨다는 것이 알려져 있으나, 두경부암에서는 KRAS 돌연변이는 3 7\%로 드물게 발견되 고 오히려 HRAS의 돌연변이가 $22 \%$ 로 보다 더 높게 보고된 바가 있다. ${ }^{14)}$ 두경부암에서의 RAS 돌연변이의 역할에 관하여 는 보다 많은 연구가 진행되어야 할 것으로 보인다.

\section{$\mathrm{PI} 3 \mathrm{~K} / \mathrm{AKT}$ 경로 활성화}

EGFR 억제제의 저항성 기전의 한 가지로 phosphatase and tensin homolog(PTEN)의 돌연변이 혹은 발현 저하로 인해 이 것이 조절하는 PI3K/AKT 경로가 활성화되는 것이 알려져 있 다. 이를 통해 암세포의 증식, 세포 고사 억제의 작용을 할 뿐 아니라 vascular endothelial growth factor(VEGF)를 통한 혈 관 신생 조절 및 상피-간질세포 이행(epithelial-mesenchymal transition, EMT)을 통한 종양세포의 침습, 전이에도 관여한 다. ${ }^{15)}$ 따라서 이러한 경우 PI3K/AKT 경로 억제제 혹은 $\mathrm{mTOR}$ 억제제를 병합요법으로서 처리하여 EGFR 저항성을 극복하 고자 하는 연구들이 진행 중이다. D'Amato 등 ${ }^{16)}$ 은 cetuximab 에 저항성을 보이는 여러 두경부암 세포주에 $\mathrm{PI} 3 \mathrm{~K} / \mathrm{mTOR}$ 동 시 억제제인 PKI-587를 cetuximab과 병합요법으로 처리하였 을 때 효과적인 암세포 억제 및 사멸 효과를 보여 EGFR 저항 성이 극복되었음을 확인하였다. Wang 등고도 유사하게 cetuximab 저항성 두경부암 세포주에서 cetuximab과 mTOR 억제제를 병합 투여하였을 때 탁월한 암세포 억제 효과가 극 대화되는 것을 보인 바 있다.

\section{EMT}

상피-간질세포 이행(EMT)이란 세포 형태 변화와 더불어 세 포 극 소실과 세포-세포 간 접촉 소실을 나타내는 현상으로 vimentin 발현 증가, E-cadherin 감소, 그리고 claudin 4/7 발
현 감소를 특징으로 한다. ${ }^{18)}$ EMT가 cetuximab, gefitinib ${ }^{15)}$ 의 저항성에 기여한다고 알려져 있으며, Yoshikawa 등이은 암 줄기세포가 oxidative stress로부터 피할 수 있는 항산화 시스 템(antioxidant system)을 표적으로 하여 억제를 할 경우 EGFR 저항성을 보이는 암세포의 EGFR에 대한 감수성을 증가시킬 수 있다고 보고하였다.

\section{Angiogenesis}

EGFR 억제제에 대한 저항성 기전으로 대두된 것이 혈관 신생(angiogenesis)의 이상 조절이다. Viloria-Petit 등은 은 항 EGFR 항체에 저항성을 보이는 6개의 세포주를 만들어 parental cell에 비해서 VEGF 발현이 증가되어 있음을 보인 바 있다. 또한 Ciardiello 등른 은 cetuximab 저항성 암세포주 를 만들어 VEGF의 발현과 분비가 증가되어 있음을 보고하 였고, EGFR/VEGFR 동시 억제 TKI인 ZD6474를 처리하였 을 때 EGFR 저항성 종양세포의 성장을 유의하게 억제할 수 있음을 보인 바 있다.

\section{HER2 표적 치료}

다른 HER family와는 달리 HER2는 리간드 결합 부위가 없고 다른 HER family member와 결합하여 신호를 증폭하 는 역할을 가진다. HER2는 heterodimerization을 일으키는 HER family 수용체에 따라 주로 관여하는 신호가 차이를 보 이는데, EGFR/HER2는 주로 MAPK 경로를 활성화시키는 반면, HER2/HER3 복합체는 MAPK뿐만 아니라 PI3K/AKT 경로의 신호도 증가시킨다(Fig. 1). HER2는 위암, 폐암, 유방암 을 비롯하여 여러 암에서 증폭 및 과발현이 되어 있음이 알려 져 있다. ${ }^{22)}$ 두경부암에서는 HER2 과발현이 0 47\%까지 다양 하게 보고되고 있다. ${ }^{23)} \mathrm{HER} 2$ 역시 과발현이 두경부암의 나쁜 예후, 재발률 증가 및 생존율 감소와 연관이 있다. ${ }^{24)}$ 두경부 암에서는 EGFR과 함께 HER2의 과발현이 동반되는 경우가 흔한데, 따라서 전술하였듯이 EGFR 억제제의 저항성의 대표 적인 기전으로 HER2 과발현을 들 수가 있고 이 두 신호를 동 시에 억제하는 병합요법에 대한 연구가 많이 이루어졌다. ${ }^{25}$

HER2에 대한 표적 치료제로서는 trastuzumab, pertuzum$\mathrm{ab}$ 과 같은 mAb와 lapatinib(가역적 EGFR, HER2 억제제), afatinib(비가역적 EGFR, HER2, HER4 억제제), dacomitinib (비가역적 범HER 억제제) 등의 TKI 제제가 개발되어 두경부 암에 대해서 연구가 진행 중이다. ${ }^{26}$

\section{cMET 표적 치료}

cMET은 RTK의 하나로서 hepatocyte growth factor(HGF) 가 알려진 유일한 리간드이다. HGF가 cMET에 결합하게 되면 
dimerization을 일으켜 Grb2와 Gab1을 통해 다른 RTK와 공통으로 여러 하부 신호전달 체계를 활성화시키는데, MAPK, PI3K/AKT, janus kinase(JAK)/STAT 경로 등이 있다. 또한 E-cadherin 감소, $\beta$-catenin과 micro-RNA 증가 등을 통해 EMT에도 관여하는 것으로 알려져 있다. 두경부암에서는 $\mathrm{HGF}-\mathrm{cMET}$ 경로의 이상 조절을 보이는 경우가 흔한데, $\mathrm{cMET}$ 증폭, 돌연변이, 과발현, cMET를 억제하는 cellular phosphatase의 downregulation, EGFR과 crosstalk 등의 기전을 통해 cMET가 활성화되어 있다. ${ }^{27)}$

$\mathrm{cMET}$ 표적 치료제로 개발된 약제로는 rilotumumab, ficlatuzumab, TAK-701과 같은 항 HGF mAb, onartuzumab, LY-2875358과 같은 항cMET mAb, 그리고 foretinib, crizotinib, tivatinib, cabotinib, golvatinib과 같은 TKI가 있으며 일부 두경부암을 포함한 여러 고형암에 대해 임상연구가 진 행 중이다. ${ }^{27}$ 향후 두경부암을 대상으로만 하는 보다 대규모 의 임상 연구가 진행되어야 할 것으로 보인다.

\section{$\mathrm{PI} 3 \mathrm{~K} / \mathrm{AKT} / \mathrm{mTOR}$ 경로 표적 치료와 저항성}

$\mathrm{PI} 3 \mathrm{~K} / \mathrm{AKT} / \mathrm{mTOR}$ 경로는 두경부 편평세포암종에서 가장 흔하게 이상조절을 보이는 신호전달 체계로서 약 30 50\% 정 도에서 발견된다. ${ }^{28,29)} \mathrm{PI} 3 \mathrm{~K}$ 는 여러 RTK에 의해 활성화되는데, EGFR, HER3, cMET, platelet-derived growth factor receptor, VEGFR, IGF-1R 등이 있다. 두경부암에서 EGFR의 높은 발현율과 다른 ErbB family member와 heterodimerization 을 이룬다는 사실이 PI3K 또한 자주 활성화가 일어난다는 점을 시사한다. $\mathrm{PI} 3 \mathrm{~K}$ 는 순차적으로 $\mathrm{AKT}, \mathrm{mTOR}$, 그리고 $\mathrm{p} 70$ $\mathrm{S} 6 \mathrm{~K}$ 를 활성화시키어 암세포의 성장, 증식, 생존을 촉진시킨 다. PI3K의 중심 조절인자로는 PTEN 종양억제인자가 있다. 두경부암에서는 PIK3CA, AKT 유전자의 돌연변이 및 증폭, $\mathrm{PTEN}$ 의 돌연변이 혹은 소실로 인해 $\mathrm{AKT}$ 의 과활성화가 일 어나고 $\mathrm{PI} 3 \mathrm{~K} / \mathrm{AKT} / \mathrm{mTOR}$ 신호전달이 증가하여 종양의 성장 을 촉진시킨다. PI3K/AKT/mTOR 경로의 과활성화는 항암 약물요법, 방사선요법뿐만 아니라 EGFR 표적 치료의 저항성 을 유발한다.

$\mathrm{PI} 3 \mathrm{~K} / \mathrm{AKT} / \mathrm{mTOR}$ 경로를 표적으로 개발된 약제 중에서 $\mathrm{PI} 3 \mathrm{~K}$ 억제제는 크게 범PI3K 억제제와 PI3K 아형 특이억제제 로 대별된다. PI3K family는 I, II, III형 3가지가 있고 I형은 다 시 $\mathrm{p} 110 \alpha, \mathrm{p} 110 \beta, \mathrm{p} 110 \delta$ (이상 IA형)과 $\mathrm{p} 110 \gamma(\mathrm{IB}$ 형)으로 세분 화할 수 있는데, 발암기전에서 주로 관여되는 아형은 PI3K IA 형이다. PI3K I형 모든 아형을 표적으로 하는 범PI3K 억제 제로는 buparlisib, PX-866 등이 있고 현재 두경부암에서 그 효과에 대해 전임상 혹은 임상 연구가 진행 중이다. ${ }^{30,31)}$ 두경 부암에서 주로 $\mathrm{PI} 3 \mathrm{~K} \alpha$ 아형이 많이 관여되기에 이 아형에 특
이적인 PI3K 억제제가 개발되었고, 면역체계와 관련이 있는 PI3K $\delta$ 아형 억제와는 달리 면역 독성을 보이지 않는다. BYL719 약제가 개발되어 두경부암에 효과를 보인 연구가 있으며, 또 한 cetuximab과 erlotinib의 약제 반응성을 높인다는 연구 결 과도 있다. ${ }^{31)} \mathrm{AKT}$ 억제제로는 MK-2206, perifosine, GDC0068 등이 개발되어 두경부암에서 연구 중에 있다. ${ }^{32,33}$ 또한 $\mathrm{mTOR}$ 억제제가 개발되어 everolimus, temsirolimus 등의 약제의 효 과에 대해 연구가 되었는데, ${ }^{31)}$ 이와 같이 선택적으로 $\mathrm{mTOR}$ 을 억제를 하게 될 경우 조절 기전으로 인해 $\mathrm{PI} 3 \mathrm{~K}$ 가 과활성화 되어 $\mathrm{mTOR}$ 과 재활성화되는 저항 기전이 확인됨에 따라 dual $\mathrm{PI} 3 \mathrm{~K} / \mathrm{mTOR}$ 억제제가 개발되기에 이르렀다. ${ }^{34)}$ 두경부암에 연 구가 진행된 dual PI3K/mTOR 억제제로는 BEZ235, PF04691502 등이 있다. ${ }^{35,36)}$

$\mathrm{PI} 3 \mathrm{~K} / \mathrm{AKT} / \mathrm{mTOR}$ 경로에 대한 표적 치료 역시 저항성이 확 인되었는데, $\mathrm{PI} 3 \mathrm{~K}$ 경로 억제제에 저항성을 보이는 두경부암 세포주에서 PI3K를 억제함에 따라 EGFR을 포함한 RTK와 $\mathrm{ERK}$ 등의 신호가 증가되는 것을 보였다. ${ }^{37)}$ 따라서 $\mathrm{PI} 3 \mathrm{~K}$ 와 함 께 EGFR 혹은 MEK 경로를 동시에 억제하는 병합요법을 통 해 상승 효과를 확인할 수 있었다. ${ }^{37)}$ 또한 Elkabets 등 ${ }^{38)}$ 은 PI3K 억제제에 저항성을 보이는 두경부암에서 RTK인 AXL이 과발현되어 EGFR과 dimer를 이루고 이어서 PLC $\gamma$ 와 PKC 를 차례로 활성화시켜 $\mathrm{PI} 3 \mathrm{~K}$ 와 무관하게 $\mathrm{mTOR}$ 과활성화를 야기한다는 것을 확인하였다. 나아가 PI3K 억제제와 함께 EGFR, AXL 혹은 PKC 억제제를 동시에 투여할 경우 PI3K 의 저항성이 극복된다는 것을 보고하였다. 그 밖에도 PI3K 경 로를 억제함에 따라 변화를 보이는 다른 신호전달체계로 JAK/ STAT, MAPK, NOTCH, VEGF, cMET, IGF 등이 있으며 따 라서 PI3K 억제제와 함께 이러한 신호를 표적으로 하는 억제 제와 병합요법을 고려해볼 수 있다. ${ }^{31)}$

\section{Antiangiogenic therapy}

두경부암에서 VEGF 혹은 VEGFR2/3 과발현이 흔하게 발 견되며 불량한 예후와 연관이 있다. ${ }^{39)}$ 혈관신생을 억제하는 표적 치료는 아직도 많은 경우에서 단독 억제제를 투여하였 을 때 저항성이 나타나서 이에 대한 더 많은 연구가 필요한 실 정이다. Bevacizumab은 대표적인 VEGF mAb 억제제로서 Gyanchandani 등 ${ }^{40}$ 은 bevacizumab에 후천성 저항성을 가 지게 되는 두경부암에서 ERK 신호 증가를 통해 fibroblast growth factor 2 와 fibroblast growth factor receptor 3 의 발현이 증가되는 것을 확인하였으며, FGFR을 억제함으로써 bevacizumab에 대한 저항성이 극복되는 것을 보고하였다. 이 밖에도 다중 TKI인 sorafenib과 sunitinib이 개발되어 두경 부암에서 연구가 진행 중이다. ${ }^{41,42)}$ 


\begin{abstract}
결 론
두경부 편평세포암종은 고도로 이질성을 보이는 질환으로 EGFR의 높은 발현율에도 불구하고 EGFR 표적 치료에 대 한 저항성을 보이는 경우가 흔하다. 게다가 EGFR 신호 전달 은 다양한 내인성, 외인성 발암 신호전달 체계와 상호 작용 을 보이며 환자마다 제각기 다른 저항성 기전을 보일 수 있 다. 이 외에도 두경부 종양세포의 다른 표적으로 개발된 치료 에도 다양한 저항성 기전을 보이기도 한다. 다중병합요법이 효과적인 환자가 있는가 하면 여러 약제를 동시에 치료를 함 으로써 단순히 독성만 증가시키는 환자도 있을 것이다. 따라 서 개개인에 최적화된 표적 치료(precision medicine)를 위 해서는 다양한 유전체적(genomic), 단백체적(proteomic) 바 이오마커를 개발하여 EGFR을 비롯한 여러 표적 치료의 반 응성을 예측하여 가장 적합한 표적 치료제를 선택하거나 여러 신호전달 체계가 관여되어 있을 경우 최적의 다중병합요법을 선정하여 환자의 치료 효과를 극대화해야 할 것이다.
\end{abstract}

\section{REFERENCES}

1) Siegel R, Naishadham D, Jemal A. Cancer statistics, 2013. CA Cancer J Clin 2013;63(1):11-30.

2) Yonesaka K, Zejnullahu K, Okamoto I, Satoh T, Cappuzzo F, Souglakos J, et al. Activation of ERBB2 signaling causes resistance to the EGFR-directed therapeutic antibody cetuximab. Sci Transl Med 2011;3(99):99ra86.

3) Harrington KJ, El-Hariry IA, Holford CS, Lusinchi A, Nutting $\mathrm{CM}$, Rosine D, et al. Phase I study of lapatinib in combination with chemoradiation in patients with locally advanced squamous cell carcinoma of the head and neck. J Clin Oncol 2009;27(7):1100-7.

4) Erjala K, Sundvall M, Junttila TT, Zhang N, Savisalo M, Mali P, et al. Signaling via ErbB2 and ErbB3 associates with resistance and epidermal growth factor receptor (EGFR) amplification with sensitivity to EGFR inhibitor gefitinib in head and neck squamous cell carcinoma cells. Clin Cancer Res 2006;12(13):4103-11.

5) Harari PM, Wheeler DL, Grandis JR. Molecular target approaches in head and neck cancer: epidermal growth factor receptor and beyond. Semin Radiat Oncol 2009;19(1):63-8.

6) Boehm AL, Sen M, Seethala R, Gooding WE, Freilino M, Wong $\mathrm{SM}$, et al. Combined targeting of epidermal growth factor receptor, signal transducer and activator of transcription-3, and Bcl-X(L) enhances antitumor effects in squamous cell carcinoma of the head and neck. Mol Pharmacol 2008;73(6):1632-42.

7) Knowles LM, Stabile LP, Egloff AM, Rothstein ME, Thomas SM, Gubish CT, et al. HGF and c-Met participate in paracrine tumorigenic pathways in head and neck squamous cell cancer. Clin Cancer Res 2009;15(11):3740-50.

8) Seiwert TY, Jagadeeswaran R, Faoro L, Janamanchi V, Nallasura $\mathrm{V}$, El Dinali M, et al. The MET receptor tyrosine kinase is a potential novel therapeutic target for head and neck squamous cell carcinoma. Cancer Res 2009;69(7):3021-31.

9) Stabile LP, He G, Lui VW, Thomas S, Henry C, Gubish CT, et al. c-Src activation mediates erlotinib resistance in head and neck cancer by stimulating c-Met. Clin Cancer Res 2013;19(2):380-92.

10) Ratushny V, Astsaturov I, Burtness BA, Golemis EA, Silverman JS. Targeting EGFR resistance networks in head and neck cancer. Cell
Signal 2009;21(8):1255-68.

11) Schmitz S, Ang KK, Vermorken J, Haddad R, Suarez C, Wolf GT, et al. Targeted therapies for squamous cell carcinoma of the head and neck: current knowledge and future directions. Cancer Treat Rev 2014; 40(3):390-404

12) Schmitz S, Kaminsky-Forrett MC, Henry S, Zanetta S, Geoffrois L, Bompas E, et al. Phase II study of figitumumab in patients with recurrent and/or metastatic squamous cell carcinoma of the head and neck: clinical activity and molecular response (GORTEC 200802). Ann Oncol 2012;23(8):2153-61.

13) Sok JC, Coppelli FM, Thomas SM, Lango MN, Xi S, Hunt JL, et al. Mutant epidermal growth factor receptor (EGFRvIII) contributes to head and neck cancer growth and resistance to EGFR targeting. Clin Cancer Res 2006;12(17):5064-73.

14) Stransky N, Egloff AM, Tward AD, Kostic AD, Cibulskis K, Sivachenko A, et al. The mutational landscape of head and neck squamous cell carcinoma. Science 2011;333(6046):1157-60.

15) Frederick BA, Helfrich BA, Coldren CD, Zheng D, Chan D, Bunn $\mathrm{PA} \mathrm{Jr}$, et al. Epithelial to mesenchymal transition predicts gefitinib resistance in cell lines of head and neck squamous cell carcinoma and non-small cell lung carcinoma. Mol Cancer Ther 2007;6(6):168391.

16) D’Amato V, Rosa R, D’Amato C, Formisano L, Marciano R, Nappi L, et al. The dual PI3K/mTOR inhibitor PKI-587 enhances sensitivity to cetuximab in EGFR-resistant human head and neck cancer models. Br J Cancer 2014;110(12):2887-95.

17) Wang Z, Martin D, Molinolo AA, Patel V, Iglesias-Bartolome R, Degese MS, et al. mTOR co-targeting in cetuximab resistance in head and neck cancers harboring PIK3CA and RAS mutations. J Natl Cancer Inst 2014;106(9). http://dx.doi.org/10.1093/jnci/dju215.

18) Thomson S, Buck E, Petti F, Griffin G, Brown E, Ramnarine N, et al. Epithelial to mesenchymal transition is a determinant of sensitivity of non-small-cell lung carcinoma cell lines and xenografts to epidermal growth factor receptor inhibition. Cancer Res 2005;65(20): 9455-62.

19) Yoshikawa M, Tsuchihashi K, Ishimoto T, Yae T, Motohara $T$, Sugihara E, et al. xCT inhibition depletes CD44v-expressing tumor cells that are resistant to EGFR-targeted therapy in head and neck squamous cell carcinoma. Cancer Res 2013;73(6):1855-66.

20) Viloria-Petit A, Crombet T, Jothy S, Hicklin D, Bohlen P, Schlaeppi $\mathrm{JM}$, et al. Acquired resistance to the antitumor effect of epidermal growth factor receptor-blocking antibodies in vivo: a role for altered tumor angiogenesis. Cancer Res 2001;61(13):5090-101.

21) Ciardiello F, Bianco R, Caputo R, Caputo R, Damiano V, Troiani T, et al. Antitumor activity of ZD6474, a vascular endothelial growth factor receptor tyrosine kinase inhibitor, in human cancer cells with acquired resistance to antiepidermal growth factor receptor therapy. Clin Cancer Res 2004;10(2):784-93.

22) Yarden $Y$, Sliwkowski MX. Untangling the ErbB signalling network. Nat Rev Mol Cell Biol 2001;2(2):127-37.

23) Cavalot A, Martone T, Roggero N, Brondino G, Pagano M, Cortesina G. Prognostic impact of HER-2/neu expression on squamous head and neck carcinomas. Head Neck 2007;29(7):655-64.

24) Xia W, Lau YK, Zhang HZ, Liu AR, Li L, Kiyokawa N, et al. Strong correlation between c-erbB-2 overexpression and overall survival of patients with oral squamous cell carcinoma. Clin Cancer Res 1997; 3(1):3-9.

25) Ibrahim SO, Lillehaug JR, Johannessen AC, Liavaag PG, Nilsen R, Vasstrand EN. Expression of biomarkers (p53, transforming growth factor alpha, epidermal growth factor receptor, c-erbB-2/neu and the proliferative cell nuclear antigen) in oropharyngeal squamous cell carcinomas. Oral Oncol 1999;35(3):302-13.

26) Pollock NI, Grandis JR. HER2 as a therapeutic target in head and neck squamous cell carcinoma. Clin Cancer Res 2015;21(3):526-33. 
27) Nisa L, Aebersold DM, Giger R, Zimmer Y, Medová M. Biological, diagnostic and therapeutic relevance of the MET receptor signaling in head and neck cancer. Pharmacol Ther 2014;143(3):337-49.

28) Liu P, Cheng H, Roberts TM, Zhao JJ. Targeting the phosphoinositide 3-kinase pathway in cancer. Nat Rev Drug Discov 2009;8(8):627-44.

29) Lui VW, Hedberg ML, Li H, Vangara BS, Pendleton K, Zeng Y, et al. Frequent mutation of the PI3K pathway in head and neck cancer defines predictive biomarkers. Cancer Discov 2013;3(7):761-9.

30) Erlich RB, Kherrouche Z, Rickwood D, Endo-Munoz L, Cameron S, Dahler A, et al. Preclinical evaluation of dual PI3K-mTOR inhibitors and histone deacetylase inhibitors in head and neck squamous cell carcinoma. Br J Cancer 2012;106(1):107-15.

31) Simpson DR, Mell LK, Cohen EE. Targeting the PI3K/AKT/mTOR pathway in squamous cell carcinoma of the head and neck. Oral Oncol 2015;51(4):291-8.

32) Argiris A, Cohen E, Karrison T, Esparaz B, Mauer A, Ansari R, et al. A phase II trial of perifosine, an oral alkylphospholipid, in recurrent or metastatic head and neck cancer. Cancer Biol Ther 2006;5(7): 766-70.

33) Molife LR, Yan L, Vitfell-Rasmussen J, Zernhelt AM, Sullivan DM, Cassier PA, et al. Phase 1 trial of the oral AKT inhibitor MK-2206 plus carboplatin/paclitaxel, docetaxel, or erlotinib in patients with advanced solid tumors. J Hematol Oncol 2014;7:1.

34) O'Reilly KE, Rojo F, She QB, Solit D, Mills GB, Smith D, et al. mTOR inhibition induces upstream receptor tyrosine kinase signaling and activates Akt. Cancer Res 2006;66(3):1500-8.

35) Fokas E, Im JH, Hill S, Yameen S, Stratford M, Beech J, et al. Dual inhibition of the PI3K/mTOR pathway increases tumor radiosensitivity by normalizing tumor vasculature. Cancer Res 2012;72(1):239-48.
36) Herzog A, Bian Y, Vander Broek R, Hall B, Coupar J, Cheng H, et al. $\mathrm{PI} 3 \mathrm{~K} / \mathrm{mTOR}$ inhibitor PF-04691502 antitumor activity is enhanced with induction of wild-type TP53 in human xenograft and murine knockout models of head and neck cancer. Clin Cancer Res 2013; 19(14):3808-19.

37) Mazumdar T, Byers LA, Ng PK, Mills GB, Peng S, Diao L, et al. A comprehensive evaluation of biomarkers predictive of response to PI3K inhibitors and of resistance mechanisms in head and neck squamous cell carcinoma. Mol Cancer Ther 2014;13(11):2738-50.

38) Elkabets M, Pazarentzos E, Juric D, Sheng Q, Pelossof RA, Brook S, et al. AXL mediates resistance to PI3K $\alpha$ inhibition by activating the EGFR/PKC/mTOR axis in head and neck and esophageal squamous cell carcinomas. Cancer Cell 2015;27(4):533-46.

39) Neuchrist C, Erovic BM, Handisurya A, Fischer MB, Steiner GE, Hollemann D, et al. Vascular endothelial growth factor $\mathrm{C}$ and vascular endothelial growth factor receptor 3 expression in squamous cell carcinomas of the head and neck. Head Neck 2003;25(6):464-74.

40) Gyanchandani R, Ortega Alves MV, Myers JN, Kim S. A proangiogenic signature is revealed in FGF-mediated bevacizumab-resistant head and neck squamous cell carcinoma. Mol Cancer Res 2013;11(12): 1585-96.

41) Williamson SK, Moon J, Huang CH, Guaglianone PP, LeBlanc M, Wolf GT, et al. Phase II evaluation of sorafenib in advanced and metastatic squamous cell carcinoma of the head and neck: Southwest Oncology Group Study S0420. J Clin Oncol 2010;28(20):3330-5.

42) Machiels JP, Henry S, Zanetta S, Kaminsky MC, Michoux N, Rommel D, et al. Phase II study of sunitinib in recurrent or metastatic squamous cell carcinoma of the head and neck: GORTEC 2006-01. J Clin Oncol 2010;28(1):21-8.

\section{정답 및 해설}

답 (2)

해 설 대부분의 뇌류는 후두부(75\%)에서 발생하며, 성별차이는 없으며 지주막하 연결을 유지한 채로 신경조직이 중추신경에서 탈출한 것을 의미한다. 조직검사 시에 뇌막염 등의 합병증이 발생할 수 있으므로 소아에서 이런 소견이 보일 때에는 조직 검사 여부를 방사선 검사 후에 결정해야 한다(대한이비인후과학 교과서 제22장 참조. 서울: 일조각;2009.). 